\title{
DOKLAD AKTIVITY NÍZKOTEPLOTNÍCH Ca-Na-CI SOLANEK VE FELDSPATITIZOVANÝCH GRANITECH ŽIVCOVÉHO LOŽISKA KRÁSNO (MASIV KRUDUM)
}

\author{
Evidence for activity of low-temperature $\mathrm{Ca}-\mathrm{Na}-\mathrm{Cl}$ brines in feldspathitized granites of the feld- \\ spar deposit near Krásno (Krudum granite body)
}

\author{
Zdeněk Dolníček', Miloš René \\ ${ }^{1}$ Katedra geologie, Univerzita Palackého, 17. listopadu 12, 77146 Olomouc; e-mail:dolnicek@prfnw.upol.cz \\ 2 Ústav struktury a mechaniky hornin Akademie věd ČR, v. v .i., V Holešovičkách 94/41, 18209 Praha
}

(11-23 Sokolov)

Key words: Karlovy Vary pluton, Krudum granite, post-magmatic alteration, fluorite, $\mathrm{Na-Ca-Cl} \mathrm{brines,} \mathrm{fault}$

\begin{abstract}
The quartz-fluorite NNW-SSE trending vein mineralization hosted by alkali-feldspar syenites and leucocratic topaz-albite granites of the Vysoký Kámen stock (Krudum granite body) formed from low-salinity (0-5 wt. \% NaCl eq.) and low-temperature (Th = 90-132 ${ }^{\circ} \mathrm{C}$ ) aqueous fluids. Both quartz and fluorite host secondary fluid inclusions which contain high-salinity (16-26 wt. \% NaCl eq.) low-temperature $\left(\mathrm{Th}=89-138^{\circ} \mathrm{C}\right) \mathrm{Ca}-\mathrm{Na}$-Cl brines. Two compositional subtypes of brines can be identified (Na-rich hosted by FI in fluorite and Ca-rich hosted by FI in quartz). The microthermometric parameters of brine-bearing fluid inclusions are fully comparable to the high-salinity fluids that participated during formation of many types of vein mineralizations during the post-Variscan period in the Bohemian Massif. The brines probably migrated along the adjacent NNW-SSE trending Vysoký Kámen fault.
\end{abstract}

\section{Úvod}

V minulých třech letech byly studovány fluidní systémy v silně alterovaných (greisenizovaných) granitech v okolí Horního Slavkova. Hlavní pozornost byla soustředěna na nejlépe odkrytou a již dříve podrobně mineralogicky, petrologicky a geochemicky studovanou lokalitu - Hubský peň, který je spolu s pněm Schnöd součástí Sn-W rudního ložiska Krásno-Horní Slavkov. Mikrotermometrické studium vzorků greisenů, rudních hnízd a hydrotermálních žil ukazuje na působení tří hlavních systémů fluid (Dolníček a René 2011, Dolníček et al. 2012):

1) Vysokosalinní (30-33 hm. \% $\mathrm{NaCl}$ ekv.) a vysokoteplotní $\left(T h=468-512{ }^{\circ} \mathrm{C}\right)$ chloridové vodné roztoky. Tato fluida byla zjištěna jen vzácně a jsou interpretována jako produkt sekundárního varu fluidní fáze uvolněné při krystalizaci granitového magmatu.

2) Nízkosalinní (0-7 hm. \% $\mathrm{NaCl}$ ekv.) a vysokoteplotní (cca $350-400{ }^{\circ} \mathrm{C}$ ) vodné roztoky s malým obsahem $(<10 \%)$ rozpuštěných plynů. Tato fluida se $\mathrm{v}$ inkluzích vyskytují velmi hojně. Způsobovala rozsáhlou greisenizaci granitů a vznik $\mathrm{Sn}-\mathrm{W}$ mineralizace.

3) Nízkosalinní $(0-9 \mathrm{hm} . \% \mathrm{NaCl}$ ekv. $)$ vodné roztoky s klesající teplotou $\left(<350\right.$ až $\left.<50^{\circ} \mathrm{C}\right)$, převážně bez mikrotermometricky detekovatelného obsahu plynných složek. Výskyt fluid tohoto typu je $\mathrm{v}$ greisenech vázán na sekundární fluidní inkluze. Tato fluida charakterizují post-greisenizační etapu, kdy během postupného chladnutí granitového tělesa docházelo ke vzniku pozdních žil se sulfidy, fluoritem a hematitem, a k argilitizaci topazu.

Odlišný typ fluid se podařilo identifikovat při studiu fluidních inkluzí ve vzorku křemen-fluoritové žiloviny ze západněji ležícího živcového ložiska Vysoký Kámen (obr. 1). Bližší charakterizace tohoto $\mathrm{v}$ daném prostř̌edí dosud nepodchyceného systému je předmětem předloženého př́spěvku.

\section{Geologická pozice a studovaná mineralizace}

Granitový peň Vysoký Kámen představuje denudační zbytek topaz-albitových granitů masivu Krudum. Na rozdíl od pnu Hub a Schnöd, obsahujících greiseny a zčásti greisenizované topaz-albitové granity s $\mathrm{Sn}-\mathrm{W}$ mineralizací, v pni Vysokého Kamene jsou zachované pouze podložníleukokratní topaz-albitové granity. Granitový peň je na $\mathrm{V}$ omezen cca $30 \mathrm{~m}$ mocnou poruchou Vysokého Kamene SSZ-JJV směru, podél níž pokleslo krystalinikum slavkovské kry a východní okraj pně, v němž zůstal zachován malý greisenový peň (ložisko Sn-W rud Vysoký Kámen) (obr. 1). Leukokratní topaz-albitové granity obsahují subhorizontální polohy bezkřemenných alkalicko-živcových syenitů, označovaných ve většině publikací jako feldspatity (Fiala a Pácal 1968, Pácal a Pavlů 1972, Breiter et al. 1999, Jarchovský 2006). Polohy syenitů jsou obvykle několik metrů až několik desítek metrů mocné a s leukokratními topaz-albitovými granity jsou spojené pozvolnými přechody. Leukokratní topaz-albitové granity obsahují vzácně nepravidelné čočky nebo žíly pegmatitů. Pro některé pegmatitové žíly je charakteristická př́tomnost vyrostlic K-živce, které jsou orientované kolmo k okraji žíly. Tento jev je typický pro okrajové pegmatity (stockscheidery), které jsou v granitových pních Hub a Schnöd vyvinuty na rozhraní granitů a okolních metasedimentů.

Jak leukokratní granity, tak alkalicko-živcové syenity jsou postižené následnou albitizací a draselnou feldspatitizací, místy i greisenizací.

Ve vlastním pni je vyvinuta řada různě výrazných puklin SSZ-JJV až SZ-JV směru paralelních s okrajovým zlomem Vysokého Kamene. Pukliny jsou často vyplněné křemennými nebo hematit-křemennými čočkami a žila- 


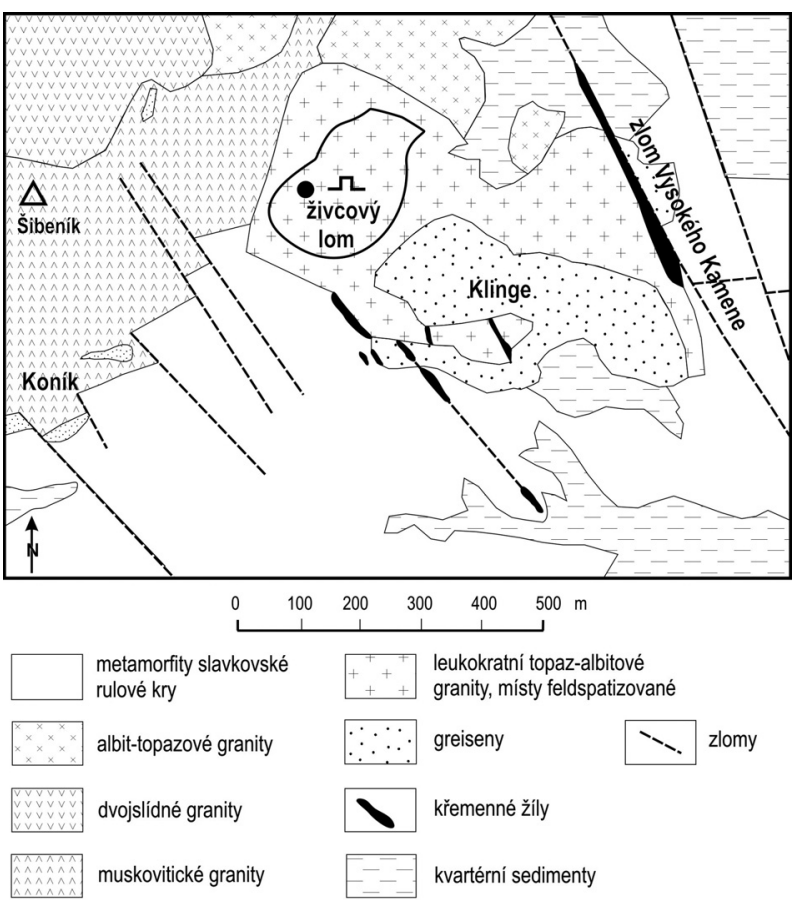

Obr. 1: Geologická mapa granitového pně Vysoký Kámen (upraveno podle Fialy a Pácala 1968). Černý bod indikuje místo odběru vzorku.

Fig. 1: Geological map of the Vysoký Kámen granite stock (modified from Fiala and Pácal 1968). The black point indicates the location of the studied sample.

mi, jejichž mocnost se pohybuje od několika centimetrů do $10-20 \mathrm{~cm}$. V některých prrípadech jsou tyto pukliny vyplněné drobnými žilkami nebo velmi nepravidelnými čočkami obsahujícími fluorit spolu s křemenem, obvykle 0,5-2 cm mocnými. Fluorit je většinou starší než křemen; byly však pozorovány i drobné krystalky křemene zarostlé v určitých růstových zónách fluoritových krystalů. Fluoritová zrna jsou často zonální již v polarizačním mikroskopu (střídání fialových a bezbarvých zón). Detailní zonálnost je pak viditelná v mikroskopu vybaveném optickou katodovou luminiscencí (viz obrázek na obálce časopisu). Starší fluorit má převážně tmavě modrou luminiscenci s ojedinělými světlejšími (světle modrými či žlutozelenými) zónami. $\mathrm{V}$ mladším fluoritu převažují zóny se světle modrou a žlutozelenou luminiscencí, $v$ malé míre se vyskytují i tmavě modré či oranžové odstíny. Lokálně je vyvinuta i sektorová stavba krystalů.

\section{Metodika}

Fluidní inkluze byly studovány petrograficky a mikrotermometricky. Ze vzorku byla zhotovena standardní oboustranně leštěná destička, lepená za studena vteřinovým lepidlem. V inkluzích byla konstatována přítomnost vodného roztoku (L) a plynné fáze $(\mathrm{V})$. Termometrické parametry byly získány na aparatuře Linkam THMSG 600 instalované na polarizačním mikroskopu Olympus BX-51 (Katedra geologie PřF UP v Olomouci). V inkluzích byly měřeny následující parametry: homogenizační teplota (Th), teplota zamrznutí (Tf), teplota iniciálního tání (Ti), a teploty tání ledu (Tm ledu) a hydrohalitu (Tm hydrohalitu). Salinita fluid byla počítána z teplot tání ledu podle
Bodnara (1993), případně vyjádřena graficky s použitím fázového diagramu pro systém $\mathrm{NaCl}-\mathrm{CaCl}_{2}-\mathrm{H}_{2} \mathrm{O}$ (Oakes et al. 1990, Shepherd et al. 1985).

\section{Fluidní inkluze}

Fluidní inkluze byly studovány ve vzorku křemenné žiloviny s fluoritem. Měřitelné inkluze obsahovaly oba minerály. Primární inkluze jsou izometrické, rozložené podél růstových zón nebo jsou solitérní. V obou minerálních fázích převažují inkluze typu $\mathrm{L}+\mathrm{V}$ se stálým stupněm zaplnění (plynná bublina zaujímá cca 5 obj. \%), ojedinělé jsou inkluze typu L, vyplněné pouze kapalinou (patrně metastabilita fázového složení inkluzí). Velikost primárních inkluzí dosahuje až $32 \mu \mathrm{m}$. Jak v křemeni, tak ve fluoritu jsou dále hojně přítomny primárně-sekundární či sekundární (PS-S) inkluze. Jsou plochého tvaru, rozložené podél vyhojených mikrotrhlin, o velikosti až $38 \mu \mathrm{m}$. $\mathrm{Z}$ pohledu fázového složení náleží výhradně typu $\mathrm{L}+\mathrm{V}$ (plynná bublina zaujímá stálých cca 5 obj. \%).

Mikrotermometrická měření inkluzí jsou graficky prezentována na obr. 2. Primární inkluze $\mathrm{v}$ křemeni i fluoritu homogenizují za teplot mezi 90 a $132{ }^{\circ} \mathrm{C}$. Ojediněle byly získány i výrazně vyšší hodnoty Th $\left(\operatorname{nad} 200^{\circ} \mathrm{C}\right.$; u inkluzí v křemeni), které lze však patrně vysvětlit heterogenně zachycenou plynnou fází, nebo redistribucí fází při procesu zrání inkluzí (necking-down). Uzavřené roztoky jsou v obou př́padech nízkosalinní, vypočítaná salinita se pohybuje mezi 0,0 a 4,8 hm. \% NaCl ekv. (podle hodnot Tm ledu mezi 0,0 a $-2,9^{\circ} \mathrm{C}$ ). Teploty iniciálního tání kolem $-37^{\circ} \mathrm{C}$ nasvědčují přítomnosti chloridů sodíku a hořříku a/nebo železa.

Primárně-sekundární či sekundární inkluze v obou minerálech náleží dvěma kompozičním typům fluid. Inkluze prvého typu obsahují fluidní fázi se stejnými mikrotermometrickými charakteristikami jako mají primární inkluze: $\mathrm{Th}=92-106^{\circ} \mathrm{C}, \mathrm{Tf}=-38$ až $-41^{\circ} \mathrm{C}$, Tm ledu $=-0,2$ až $-1,1^{\circ} \mathrm{C}$, salinita $0,4-1,9 \mathrm{hm}$. $\% \mathrm{NaCl}$ ekv. PS-S inkluze druhého typu homogenizují za teplot $89-138^{\circ} \mathrm{C}$. Inkluze obsahují vodný roztok, který zamrzá za teplot -51 až $-94^{\circ} \mathrm{C}$, přičemž obsah inkluzí zhnědne a často i získá granulární strukturu. To spolu s naměřenými teplotami iniciálního

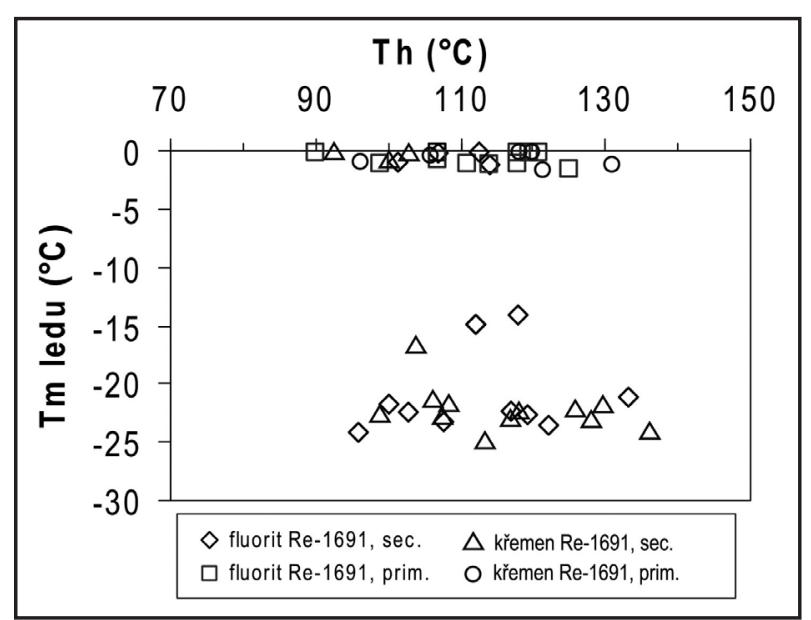

Obr. 2: Diagram Th-Tm pro křemen-fluoritové žíly z Krásna. Fig. 2: Th-Tm plot for quartz-fluorite vein from Krásno. 


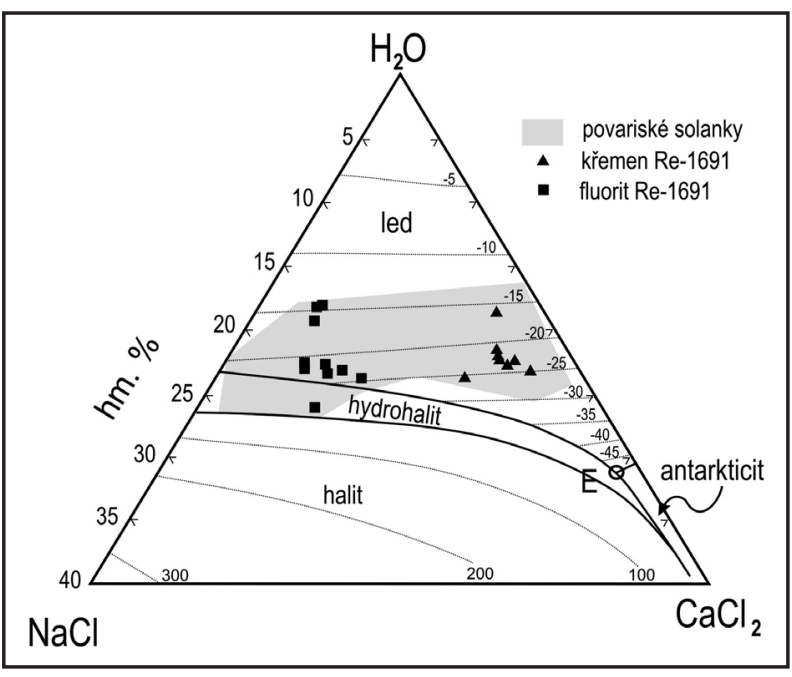

Obr. 3: Průmět naměřených kryometrických dat vysokosalinních sekundárních inkluzí $\mathrm{z}$ křemene a fluoritu ve fázovém diagramu systému $\mathrm{CaCl}_{2}-\mathrm{NaCl}-\mathrm{H}_{2} \mathrm{O}$ (Oakes et al. 1990). Data z povariských solanek převzata z Dolníčka et al. (2009).

Fig. 3: Cryometric data of high-salinity secondary fluid inclusions in quartz and fluorite in a phase diagram of the system $\mathrm{CaCl}_{2}$ $\mathrm{NaCl}-\mathrm{H}_{2} \mathrm{O}$ (Oakes et al. 1990). Field of post-Variscan brines is after Dolníček et al. (2009).

tání $\left(-52\right.$ až $\left.-68^{\circ} \mathrm{C}\right)$ nasvědčuje přítomnosti systému $\mathrm{NaCl}-$ $-\mathrm{CaCl}_{2}-\mathrm{H}_{2} \mathrm{O}$. Ve většině inkluzí taje jako předposlední pevná fáze hydrohalit (v křemeni za teplot $-31,8$ až $-37,0^{\circ} \mathrm{C}$, ve fluoritu za teplot $-23,3$ až $-26,0^{\circ} \mathrm{C}$ ) a jako poslední fáze led (v křemeni za teplot $-16,4$ až $-25,9^{\circ} \mathrm{C}$, ve fluoritu za teplot $-12,3$ až $\left.-24,2^{\circ} \mathrm{C}\right)$. Jediná inkluze ve fluoritu vykázala opačnou posloupnost tání obou fází (Tm ledu $=-24,8{ }^{\circ} \mathrm{C}$, Tm hydrohalitu $\left.=-6,7^{\circ} \mathrm{C}\right)$. Salinita, indikovaná $\mathrm{z}$ teplot tání poslední pevné fáze, se pohybuje v intervalu 19,8-26,1 hm. \% NaCl ekv. (křemen), resp. 16,2-25,5 hm. \% NaCl ekv. (fluorit). Subhorizontální distribuce naměřených dat v Th-Tm diagramu (obr. 2) nasvědčuje volnému chladnutí roztoků během zachytávání inkluzí. Průmět naměřených teplot tání poslední a předposlední fáze do fázového diagramu systému $\mathrm{NaCl}-\mathrm{CaCl}_{2}-\mathrm{H}_{2} \mathrm{O}$ (obr. 3) nasvědčuje prítomnosti dvou typů solanek s obdobnou salinitou a kontrastním pomèrem $\mathrm{NaCl} / \mathrm{CaCl}_{2}: \mathrm{v}$ inkluzích ve fluoritu jsou přítomny roztoky bohatší na $\mathrm{NaCl}$, kdežto v křemeni bohatší na $\mathrm{CaCl}_{2}$.

\section{Diskuze a závěr}

Nízkosalinní primární a PS-S fluidní inkluze se svou mikrotermometrickou charakteristikou zcela shodují $\mathrm{s}$ inkluzemi zastiženými $\mathrm{v}$ post-greisenizačních žilných mineralizacích Hubského pně, a to včetně žil křemen-fluoritových (Dolníček et al. 2012).

Post-greisenizační vysokosalinní nízkoteplotní fluidní inkluze systému $\mathrm{NaCl}-\mathrm{CaCl}_{2}-\mathrm{H}_{2} \mathrm{O}$ se v prostoru Hubského pně zatím nepodařilo doložit (srov. Dolníček et al. 2012). Výskyt v lomu Krásno nasvědčuje migraci solanek v závěrečných fázích vývoje hydrotermálního systému (velmi nízké Th), a to pravděpodobně až po ukončení krystalizace křemen-fluoritových žil (výskyt pouze v inkluzích rozložených podél vyhojených mikrotrhlin). Získaná data nasvědčují účasti dvou typů $\mathrm{NaCl}-\mathrm{CaCl}_{2}-\mathrm{H}_{2} \mathrm{O}$ fluid s kontrastním složením (s různým poměrem $\mathrm{Na}$ / Ca). Působení obou typů bylo vzájemně časově oddělené, nebot není dokumentováno míchání obou solanek, které by se projevilo i přítomností inkluzí se „středni“ hodnotou poměru $\mathrm{Na} / \mathrm{Ca}$ (srov. obr. 3 ).

Výskyt fluid se zcela analogickým chemickým složením je dokumentován z řady povariských žilných mineralizací z různých částí Českého masivu, a to včetně jeho severního okraje. Typickými př́klady jsou např. žilná ložiska uranu s mladší "pětiprvkovou" asociací v Jáchymově (Ondruš et al. 2003) a Zálesí (Dolníček et al. 2009), žilné polymetalické sulfidické mineralizace (Fojt et al. 2007), či nezrudnělé křemenné žíly (Novotný a Dobeš 1999). Shodným znakem je i výskyt dvou kompozičních typů s různým poměrem $\mathrm{Na} / \mathrm{Ca}$, které se na některých lokalitách mohly i mísit (např. na Zálesí; Dolníček et al. 2009). Složení solanek z Krásna se kryje s rozsahem složení povariských solanek (obr. 3). Na základě získaných údajů tedy nelze vyloučit, že i v Krásně mohlo jít o obdobné povariské solanky, migrující po znovu oživených zlomových strukturách, již dříve vyplněných křemen-fluoritovou mineralizací. Potenciální prrívodní strukturou solanek mohl být blízký zlom Vysokého Kamene SSZ-JJV směru nebo s ním paralelní struktury (obr. 1).

\section{Poděkování}

Laboratorní část práce byla podpořena granty GAČR 205/09/0540 a IGA UP PrF/2011/010. 


\section{Literatura}

Bodnar, R. J. (1993): Revised equation and table for determining the freezing point depression of $\mathrm{H}_{2} \mathrm{O}-\mathrm{NaCl}$ solutions. - Geochimica et Cosmochimica Acta 57, 683-684.

Breiter, K. - Förster, H. J. - Seltmann, R. (1999): Variscan silicic magmatism and related tin-tungsten mineralization in the Erzgebirge-Slavkovský les metallogenic province. - Mineralium Deposita, 34, 505-521.

Dolníček, Z. - Fojt, B. - Prochaska, W. - Kučera, J. - Sulovský, P. (2009): Origin of the Zálesí U-Ni-Co-As-Ag/Bi deposit, Bohemian Massif, Czech Republic: fluid inclusion and stable isotope constraints. - Mineralium Deposita, 44, 1, 81-97.

Dolníček, Z. - René, M. (2011): Podmínky greisenizace na Sn-W ložisku Krásno-Horní Slavkov: příspěvek ze studia fluidních inkluzí. - Zprávy o geologických výzkumech v roce 2010, 44, 146-148.

Dolníček, Z. - René, M. - Prochaska, W. - Kovářr, M. (2012): Fluid evolution of the Hub Stock, Horní Slavkov-Krásno Sn-W ore district, Bohemian Massif, Czech Republic. - Mineralium Deposita, DOI: 10.1007/s00126-012-0400-0.

Fiala, F. - Pácal, Z. (1968): Aplogranit albitowy z Krasna na tle aurowcow a skaleniowych Czechosloslowacji. - Biuletyn Instytut Geologiczny, 233, 119-154.

Fojt, B. - Dolníček, Z. - Hoffman, V. - Škoda, R. - Trdlička, Z. - Zeman, J. (2007): Paragenetická charakteristika ložisek Zn-Pb rud v širším okolí Horního Města u Rýmařova (Nízký Jeseník). - Acta Musei Moraviae, Scientia geologicae, 92, 3-57.

Jarchovský, T. (2006): The nature and genesis of greisen stocks at Krásno, Slavkovský les area - western Bohemian, Czech Republic. - Journal of the Czech Geological Society, 51, 201-216.

Novotný, P. - Dobeš, P. (1999): Žulová - Korálové jámy. Část II. Výzkum fluidních inkluzí. - Geologické výzkumy na Moravě a ve Slezsku v roce $1998,6,116-119$.

Oakes, C. S. - Bodnar, R. J. - Simonson, J. M. (1990): The system NaCl-CaCl $-\mathrm{H}_{2}$ O. I.: The ice liquidus at 1 atm total pressure. Geochimica et Cosmochimica Acta, 54, 603-610.

Ondruš, P. - Veselovský, F. - Gabašová, A. - Drábek, M. - Dobeš, P. - Malý, K. - Hloušek, J. - Sejkora, J. (2003): Ore-forming processes and mineral parageneses of the Jáchymov ore district. - Journal of Czech Geological Society, 48, 3-4, 157-192.

Pácal, Z. - Pavlů, D. (1972): Nové poznatky o ložisku sodno-draselných živců Vysoký kámen u Krásna. - Geologický průzkum, $14,357-360$.

René, M. - Škoda, R. (2011): Nb-Ta-Ti oxides fractionation in rare-metal granites: Krásno-Horní Slavkov ore district, Czech Republic. - Mineralogy and Petrology, 103, 37-48.

Shepherd, T. J. - Rankin, A. H. - Alderton, D. H. M. (1985): A practical guide to fluid inclusion studies. - Blackie, Glasgow and London. 